\title{
Range extension and geographic distribution of Amphisbaena mitchelli Procter, 1923 in the state of Pará, Brazil
}

\author{
Síria Ribeiro ${ }^{1,2 *}$, Alfredo P. Santos-Jr ${ }^{1}$,Lívia Carla Chagas ${ }^{3}$ and Hipócrates de Menezes Chalkidis ${ }^{4}$ \\ 1 Universidade Federal do Oeste do Pará, Laboratório de Ecologia e Comportamento Animal do Instituto de Ciências da Educação - ICED, Campus \\ Tapajós. Rua Vera Paz, s/n, Salé. 68015-110, Santarém, PA, Brazil. \\ 2 Universidade Federal do Oeste do Pará, Centro de Formação Interdisciplinar - CFI, Campus Amazônia. Avenida Mendonça Furtado, 2946, Fátima. \\ 68040-470, Santarém, PA, Brazil. \\ 3 Universidade Federal do Oeste do Pará, Curso de Licenciatura Plena em Ciências Biológicas, Campus Rondon. Rua Marechal Rondon s/n, \\ Aparecida. 68040-070, Santarém, PA, Brazil. \\ 4 Faculdades Integradas do Tapajós, Curso de Ciências Biológicas. Rua Rosa Vermelha 335, Aeroporto Velho. 68010-200, Santarém, PA, Brazil. \\ * Corresponding author. E-mail: siherp@hotmail.com
}

\begin{abstract}
We present here a new record for Amphisbaena michelli for the western of Pará State, northern Brazil. The specimen was found in the municipality of Belterra, on the right bank of the Tapajós River, and represents an expansion $c a$. $350 \mathrm{~km}$ west of the previously known geographic distribution of the species.
\end{abstract}

Amphisbaena mitchelli Procter, 1923 was described from Ilha do Marajó, state of Pará, Brazil, based on a specimen deposited in the British Museum of Natural History (BMNH 1946.8.2.31) (Gans 1963). This relatively small species is characterized by two elongated (oval) pre-cloacal pores, 203-220 body annuli, 26-29 caudal annuli, autotomic site in the sixth and seventh tail annuli, 12-14 dorsal and 14-16 ventral segments on a midbody annulus. After its description, four publications have presented new distribution data for $A$. mitchelli (Gans 1963, 1964; Hoogmoed and Avila-Pires 1991; Mott et al. 2011; Teixeira Jr. et al. 2014) and all the known records have been from the northwestern portion of the state of Maranhão to the east of the state of Pará, Brazil (Figure 1). Here we present a new record for $A$. mitchelli, which was collected in the western portion of the state of Pará. This new record contributes to the knowledge of the geographical distribution of this poorly known species.

On 20 October 2010, a specimen of Amphisbaena mitchelli (Figures 2 and 3 ) was captured by local residents of Vila Americana, an urban area of the municipality of Belterra, on the right margin of the Tapajós River and was delivered to one of the authors (LCC). The locality is in the west of the state of Pará, Brazil $\left(02^{\circ} 38^{\prime} 19.78^{\prime \prime}\right.$ S; $54^{\circ} 56^{\prime} 30.86^{\prime \prime} \mathrm{W}$; center of the urban area). The specimen was deposited in the collection of the Linha de Pesquisa em Herpetologia da Amazônia (LPHA), Laboratório de Pesquisas Zoológicas, Faculdades Integradas do Tapajós, municipality of Santarém, state of Pará, Brazil. Meristic data follow Gans and Alexander (1962) and morphometric data follows Perez et al. (2012). The measurements were taken with digital calipers having $0.01 \mathrm{~mm}$ precision, except for the snoutvent length, which was measured using a flexible ruler to the nearest millimeter. The voucher specimen (LPHA 4942) has the following morphological characteristics: $145 \mathrm{~mm}$ snout-vent length, an autotomized tail of 7.5 $\mathrm{mm}, 5.3 \mathrm{~mm}$ head length (3.7\% of snout-vent length), $3.9 \mathrm{~mm}$ midbody diameter, two elongate precloacal

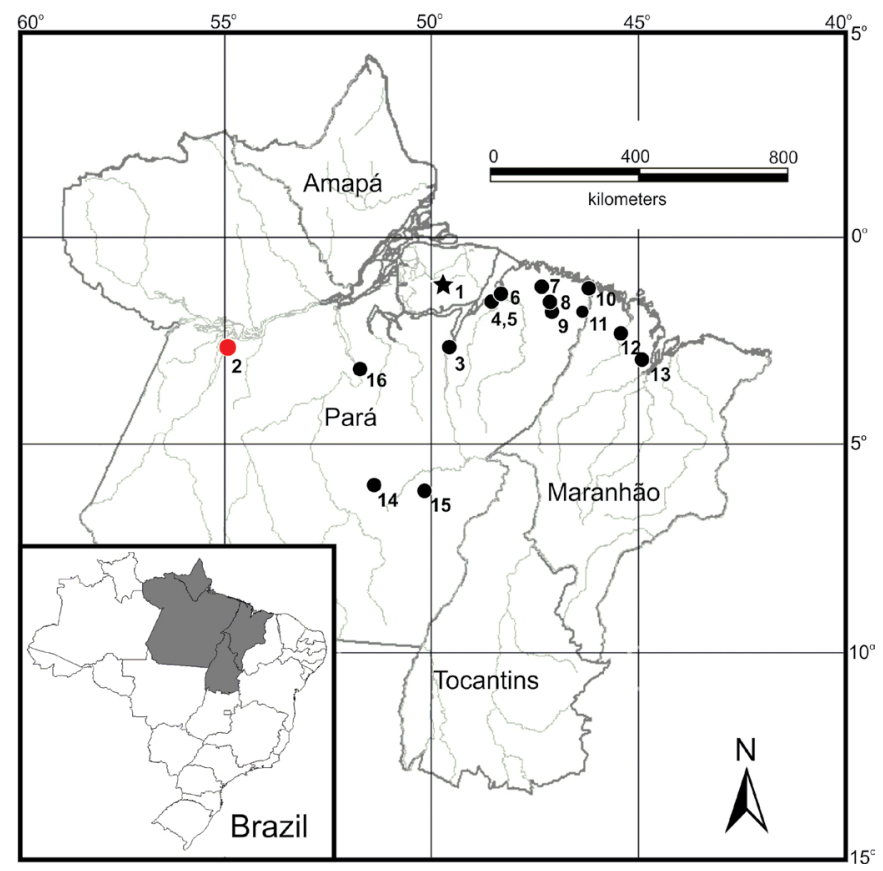

FigurE 1. Geographical distribution of Amphisbaena mitchelli. Black symbols represent records from literature (Hoogmoed and Avila-Pires 1991; Mott et al. 2011; and Teixeira Jr. et al. 2014); star represents the type-locality; red circle represents the new record for the municipality of Belterra, state of Pará, Brazil. Localities: 1, Ilha do Marajó (type locality); 2, Belterra; 3, Rio Tocantins (cf. Hoogmoed and Avila-Pires 1991); 4, Belém; 5, Ananindeua; 6, Santo Antônio do Tauá; 7, Peixe-boi; 8, Ourém; 9, Santa Luzia, Capitão Poço; 10, Viseu; 11, Colônia Nova; 12, Paruá; 13, Puraqueú; 14, Carajás; 15, Parauapebas; and 16, Juruá, Rio Xingu. 


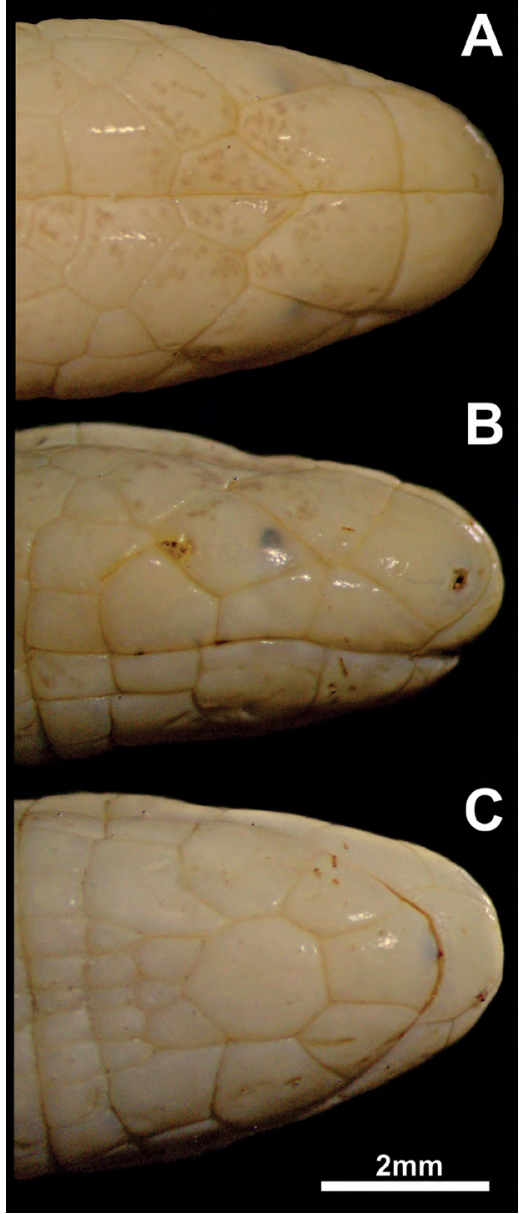

FIGURE 2. Specimen of Amphisbaena mitchelli (LPHA 4942) from municipality of Belterra, Pará state, Brazil. (A) Dorsal, (B) lateral and (C) ventral view of head.

pores (Figure 3), 213 body annuli, three lateral annuli and seven tail annuli, 13 dorsal and 16 ventral segments in an annuli at a midbody.

This is the first record of Amphisbaena mitchelli for the lower Tapajós River and extends the known distribution $c a .350 \mathrm{~km}$ west of the nearest localities (Figure 1). This new record suggests that the area of occurrence of $A$. mitchelli is broader than previously recorded, and that its occurrence in the lower Amazon region has been underestimated. Additionally, considering the importance of the zoogeographic information for conservation planning and systematic studies (Nogueira et al. 2011), new surveys are still needed to add to the knowledge of the geographical distribution of many poorly known South American amphisbaenian species [e.g., Amphisbaena acrobeles (Ribeiro, Castro-Mello \& Nogueira, 2009); A. arda Rodrigues, 2003; A. carli Pinna, Mendonça, Bocchiglieri \& Fernandes, 2010; $A$. cuiabana (Strüssmann \& Carvalho, 2001); A. kraoh Vanzolini, 1971; A. neglecta Dunn \& Piatt, 1936; A.

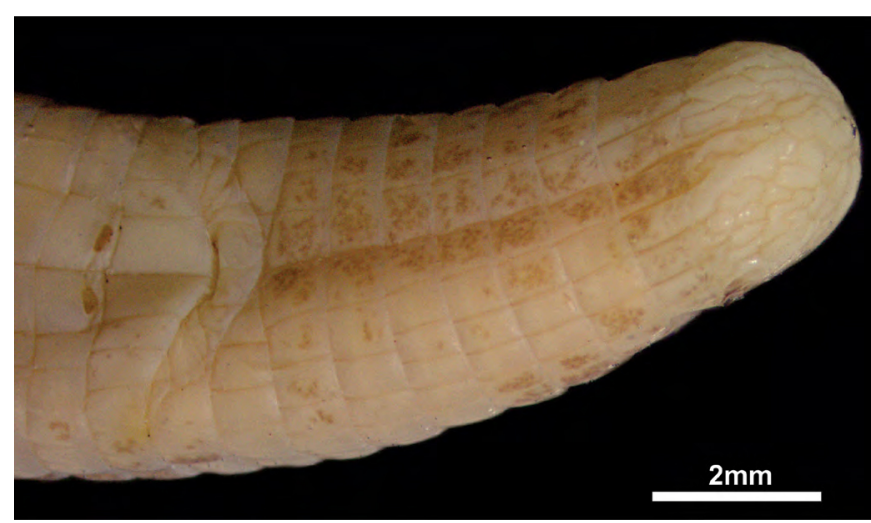

FIGURE 3. Ventral view of tail, cloaca and precloacal pores of Amphisbaena mitchelli (LPHA 4942) from municipality of Belterra, Pará state, Brazil.

talisae Vanzolini, 1995; Mesobaena huebneri Mertens, 1925; Mesobaena rhachicephala Hoogmoed, Pinto, Rocha \& Pereira, 2009].

ACKNOWLEDGEMEnTS: We thank E. Xavier for delivering the captured specimen. We are thankful of P.H. Pinna, P.M.S. Nunes and anonymous reviewer for comments and suggestions; and C.S. Oliveira for help with photographs.

\section{LITERATURE CITED}

Gans, C. 1963. Notes on amphisbaenids (Amphisbaenia, Reptilia). 7. Redescription and redefinition of Amphisbaena mitchelli Procter and Amphisbaena slevini Schmidt from the Middle and Lower Amazon, Brazil. American Museum Novitates 2127: 1-22 (http://hdl.handle. net/2246/3375).

Gans, C. 1964. Amphisbaena mitchelli Procter recorded from Belém, Pará, Brazil. Herpetologica 20(3): 192-194 (doi: 10.2307/3891042).

Gans C. and A.A. Alexander 1962. Studies on amphisbaenids (Amphisbaenia, Reptilia). 2. On the amphisbaenids of the Antilles. Bulletin of the Museum of Comparative Zoology 128(3): 65-158 (http://www.biodiversitylibrary.org/page/4284282).

Hoogmoed, M.S. and T.C.S. Avila-Pires. 1991. A new species of small Amphisbaena (Reptilia: Amphisbaenia: Amphisbaenidae) from western Amazonian, Brazil. Boletim do Museu Paraense Emilio Goeldi, Serie Zoologia 7(1): 77-94.

Mott T., D.D.S. Carvalho Neto and K.D.S. Carvalho Filho. 2011. Amphisbaena miringoera Vanzolini, 1971 (Squamata: Amphisbaenidae): New state record. Check List 7(5): 594-595 (http://www.checklist. org.br/getpdf?NGD108-11).

Nogueira, C., S. Ribeiro, G.C. Costa and G.R. Colli. 2011. Vicariance and endemism in a Neotropical savanna hotspot: distribution patterns of Cerrado squamate reptiles. Journal of Biogeography 38: 1907-1922 (doi: 10.1111/j.1365-2699.2011.02538.x)

Perez, R., S. Ribeiro and S. and M. Borges-Martins. 2012. Reappraisal of the taxonomic status of Amphisbaena prunicolor (Cope 1885) and Amphisbaena albocingulata Boettger 1885 (Amphisbaenia: Amphisbaenidae). Zootaxa 3550: 1-25.

Procter, J. 1923. On new and rare reptiles from South America. Proceedings of the Zoological Society of London for 1923 93(4): 1061-1067 (doi: 10.1111/j.1096-3642.1923.tb02220.x).

Teixeira Jr, M., F. Dal Vechio, A.M Neto and M.T. Rodrigues. 2014. A new two-pored Amphisbaena Linnaeus, 1758, from Western Amazonia, Brazil (Amphisbaenia: Reptilia). South American Journal of Herpetology 9(1): 62-74 (doi: 10.2994/SAJH-D-14-00004.1).

RECEIVED: February 2014

ACCEPTED: September 2014

Published OnLINE: October 2014

EDITORIAL RESPONSIBILITY: Pedro Nunes 